\title{
The tale of two pension reforms: A US-Japan comparison
}

Received (in revised form): 25th October, 2006

\section{Elmer Huh}

is Senior Vice President in the Enterprise Valuation Group for Lehman Brothers, Fixed Income Department. His responsibilities include developing quantitative valuation models to aid investment decisions of clients. Previously, he worked for more than eight years at Morgan Stanley where he was responsible for advising clients on accounting and regulatory issues as well as various products which helped clients understand the interaction between enterprise risk, capital employed, financial leverage and intrinsic value. Prior to Morgan Stanley, his experience in financial services included associate analysts positions at BancBoston Robertson Stephens and the Fir Tree Value Fund. He also worked as a senior consultant for Grant Thornton's Management Consulting Division concentrating on information systems, manufacturing and operations research. He earned an MBA in finance and accounting and MS in industrial engineering and operations research from Columbia University. He also received a BS with Honors in mechanical engineering from Columbia University's School of Engineering. In September 2001, he was awarded the Chartered Financial Analyst (CFA) charter.

\section{Sarah McLellan}

is a research analyst for Morgan Stanley. She graduated Summa Cum Laude from Tufts University with a double major of International Relations (Japan) and Quantitative Economics. She received her MBA from the Wharton School and MA in International Affairs (Japan) from the Lauder Institute at the University of Pennsylvania. She began looking at Japan's pension crisis in 1999 as a Fulbright Fellow at Osaka University and received the 2004 Reginald H. Jones Thesis Prize for her MA thesis on corporate pension reform in Japan.

Abstract This paper tackles the mutually vexing issue of corporate pension reform in the US and Japan. Both countries are undergoing structural and demographic changes in their workforce and corporate governance, giving urgency to the problem of pension funding and solvency. Urgency has led to different responses at the political, corporate and societal levels. Behind this, we find legacy institutions and norms peculiar to each country that are evolving under different economic realities. Pensions (2006) 12, 33-42. doi:10.1057/palgrave.pm.5950040

Keywords: Japan, pension, accounting

\section{Introduction}

As baby-boomers begin to retire in both countries over the next several years, we expect the realities of an ageing society to set in. We further expect that these realities will foster urgency towards current standards of living and how to maintain them over the next several decades. With the greying of human assets and steady declines in the dependency ratio, ${ }^{1}$ we are witnessing countries like the US and Japan demand more responsibility from their retirees to secure their post-retirement income from private sources. The corporate pension plan plays a key role in this revised social contract.

Correspondence: Sarah McLellan,

c/o Yumiko Nakayama, Morgan Stanley Japan Securities Co., Ltd., Yebisu

Garden Place Tower 5F, 4-20-3 Ebisu, Shibuya-ku,

Tokyo, 650-6008, Japan.

Tel.: 415576 2394;

Fax: 4155914541.

E-mail: sarah.mclellan@morganstanley.com
The quest for alpha or higher investment returns in the current environment promises a dependency on overseas economies to grow the retirement assets for seniors in the US and Japan. As the number of pension beneficiaries rise and the urgency of the problem takes hold, we expect the relationship between 'shareholder' and 'pension beneficiary' to deepen and help unlock the traditional tensions toward pension reform and corporate governance.

We view accounting standards, especially with the recent global changes, as an 'enabler' in this shifting mindset. While tax authorities have traditionally been the primary influence over corporate pension plans and behaviours, the mission of the tax authority is understandably more focused domestically on tax receipts and consumption behaviour. In contrast, accounting regulators have independence to 'do what's right' for the benefit of all users of financial 
information, which crosses borders and tax jurisdictions. According to the mission of the US Financial Accounting Standards Board (FASB), ${ }^{2}$ one important aspect is 'to promote the international convergence of accounting standards', which is 'concurrent with improving the quality of financial reporting'.

Integrity and usefulness of corporate financial reporting reduce informational asymmetries and transaction costs. The disclosure in turn influences corporate behaviour and investor decision making. The influence of new accounting standards on corporate behaviour may be estimated as a function of the perceived impact on corporate valuation. Accounting changes, however, can often signal a period of deeper corporate restructuring because companies will often respond to the transition period allowed by the accounting standards as a 'window of opportunity' to reorganise and drive through deeper reform. These changes evolve from a source of restructuring noise initially followed by a picture of strategic clarity. In this current 'moment of clarity', we compare Japan, which is just emerging from its restructuring efforts, to the US, which is just initiating new pension reform.

We find a common tension between preserving the current pension system and preserving the integrity, trust and competitiveness of companies through reform, increased transparency and good governance. On the national level, we see how the balance of power among the government, political leaders, the regulators, corporations, media and labour have clashed and lobbied to produce unique reform outcomes. On the other hand, the globalisation of capital flows, competition and the regional investment shifts imposed by demographics increasingly require a common platform for comparing something as peculiar and culture-laden as a nation's pension system. We view these forces as all working together to remould and align corporate pensions with the demographic challenges of this century.

\section{Impact Japan: Half financial, half personnel}

In 2000, at the low point of Japan's so-called 'lost decade', ${ }^{3}$ pension accounting standards became a tool leveraged by Japanese companies to alter the employment contract. While the CFOs of
Japanese companies grappled with pension accounting standards and the new requirements for on-balance exposure of pension reserve liabilities, the desire to shift away from the rigid steepness of the seniority-based lifetime employment contract was gaining favour in other parts of the corporate hierarchy. In particular, corporate executives viewed a shift to the flatter flexibility of a performance-based wage profile as a key restructuring prerogative. ${ }^{4}$ Inextricably linked to the rigidity of the employment contract, pensions also became inextricably linked to the solution. So, beyond mitigating the immediate financial risk to the balance sheet, companies also sought broader personnel initiatives, such as to realign employee incentives under performancebased measures, to increase the transparency of compensation costs and benefits and to foster self-responsibility for post-retirement planning. Solving for these complementary personnel objectives while reducing the financial exposure became the hallmark of corporate pension reform in Japan in response to pension accounting standards.

\section{Impact US: Accelerating the shift from traditional pension plans}

In contrast, we expect the upcoming US pension accounting changes as set forth in The Pension Protection Act of 2006 to accelerate the following two trends:

1. the freezing of traditional defined benefit (DB) plans in favour of defined contribution (DC) or hybrid plans;

2. and the re-allocation of pension assets towards longer-duration bonds. ${ }^{5,6}$

Although the continuing shift of traditional corporate pension promises into US DC or $401(\mathrm{k})^{7}$ plans will eventually remove the funding exposure for companies, it places the interest rate, longevity and investment earnings risks more squarely on the shoulders of employees. In the US, the 'social cost' of this shift became another major impetus for the recent pension legislation. As Professor Wooten ${ }^{8}$ notes, 'the PPA [Pension Protection Act] includes provisions that attempt 
to make $401(\mathrm{k})$ plans better vehicles for retirement savings by expanding participation, increasing contributions, and improving investment management'.

In the US, there is a high concentration of DB plans in unionised industries. Partly, this reflects trends in the labour markets of other industries where labour has become more fluid and the continuous retention of workers is no longer considered paramount. ${ }^{9}$ For a growing number of industries, a portable benefit in the form of a short-term promise is more appropriate. In contrast, companies in collective bargaining arrangements with unions tend to retain workers for long periods of time or effectively honour a lifetime employment contract. For employers, the trade-off associated with eliminating a DB plan is the loss of a popular mechanism to attract and retain employees and, in many cases, to induce early retirement. On the other hand, the benefits of reducing a potential cash flow crisis in the future reduces the corporation's overall exposure to reneging promises to workers, facing costly lawsuits and/or triggering public relations disasters.

Another feature of the US system, notably absent in Japan, is the Pension Benefit Guaranty Corporation (PBGC), a government-sponsored insurance agency created under the Employee Retirement Income Security Act (ERISA) of 1974. As a guarantee programme to protect workers with vested pension benefits, it has also created moral hazard, an economic problem typically associated with insurance. In this case, since companies do not ultimately bear the default risk of their plan, it reinforces the unions' and employers' mutual incentive to underfund future benefits in favour of higher current benefits, wages and promises for future benefits. ERISA attempts to mitigate this through minimum funding levels, premiums assessed to insure the companies' obligations and tax break incentives to companies to pre-fund their plans. ${ }^{10}$ By shifting most of the default risk of an underfunded plan to the PBGC, however, the system also has the adverse effect of encouraging some companies to promise more and fund less. This set the stage for a string of high-profile failures and a looming crisis at the PBGC.
In light of the increasing moral hazard created by high-profile failures and the continuing disintermediation of the corporate benefits menu, the recent legislation in the US seems to introduce enough costs, risks and investor scrutiny to tip the scales away from DB plans in favour of leaner DC structures at US companies once and for all.

\section{Looking back at reform in Japan}

\section{A 401(k) solution de-bunked}

In Japan, traditional pension plans came under scrutiny with the introduction of pension accounting standards in 2000. Companies were faltering under the weight of underfunded pension liabilities and persisting recessionary trends. ${ }^{11}$ Expectations ran high that the Defined Contribution Act of 2001 would provide necessary relief and set off a wave of plan conversion from traditional DB plans to new DC plans. New DC plans, modelled after the US 401(k), offered a way out, or so it seemed. Such a wide-scale adoption of DC plans, however, did not occur.

Some observers attributed the minimal shift towards DC plans as evidence of the corporate commitment to long-standing employment contracts and a paternalistic culture. Under this view, benevolent corporate managers might foresake change to uphold their DB promises to the bitter end even at the cost of insolvency. This interpretation was, however, inconsistent with the Japanese companies' lobbying effort for further deregulation and their public stance to advocate DC plans. As seen in Figure 1, the termination of Employer Pension Funds (EPFs) began to rise steadily from 1995, and noticeably higher from 1999 until the time of the pension reform legislation in 2001-2002.

In other words, companies were not necessarily standing behind paternalistic norms or lifetime employment contracts even before the DC legislation. To make sense of the lukewarm reaction, we take a step back and consider the backdrop to this reform.

\section{Evolving tradition}

The tradition of corporate pensions in Japan can be traced back to the Edo period (1603-1867) 


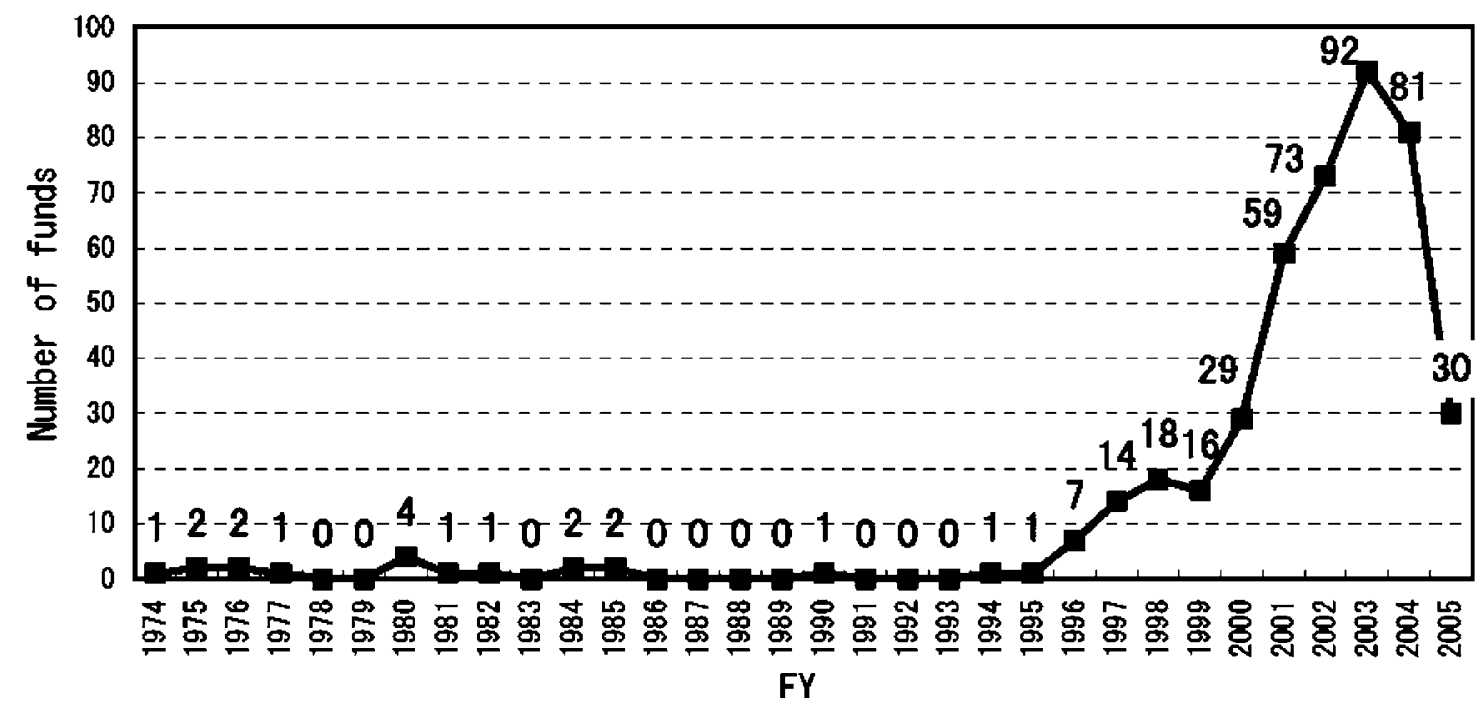

Figure 1: Number of terminated EPFs ${ }^{29}$

when tradesmen would provide employees with a lump-sum retirement allowance in recognition of long years of service. Eventually, this custom evolved into a supporting pillar of the lifetime employment contract. Embedded as such, the notion of pensions as a reward for long service proved difficult to discard at the bursting of the Bubble. An unfunding (or underfunding) of pension assets was consistent with the pillar of the lifetime employment contract because the payout to the employee was withheld until the time of retirement, not paid out (or pre-funded) over the course of the employee's service. Moreover, it was consistent with the tax treatment of contributions and benefits, a common driver of funding levels among countries.

When corporate pensions formally developed in Japan during the postwar period, the tax rules did not allow companies to expense the current contribution or pre-funding. In a strict sense, the rules did, but they also required an offset to the employee in the form of a current tax obligation regardless of whether the employee was actually receiving any benefit then or 30 years from then. To maintain labour harmony, the company typically made a concession to the employee that would exactly offset the current tax burden. As a result, companies found it more convenient to simply not pre-fund their pension assets. Given the youthful employee base and the favourable economic times, an unfunded system worked smoothly for many years with minimal cash or funding risk. As the employee base aged and companies hit a recession, however, the system revealed its flaws.

\section{The slow shock: Demographics}

The blueprint of Japan's demographic woes began to emerge in the 1990s when the inadequacy of the public pension system became apparent. Medical advances and standard of living improvements had elevated the longevity in Japan over the years to the highest of ranks globally people were living longer. In 1950, the average life expectancy beyond retirement was a few years; today, it is decades. At the same time, economic changes and societal trends were favouring smaller families and lower fertility rates. The public system's Pay-as-you-Go (PAYG) structure, which funds benefits to retirees primarily from the contributions of active workers, is best designed for the pyramid-like population structure that existed in the early postwar period. The interplay of demographics and pensions can be best understood starting from a comparison of the population pyramids in Figure 2. 

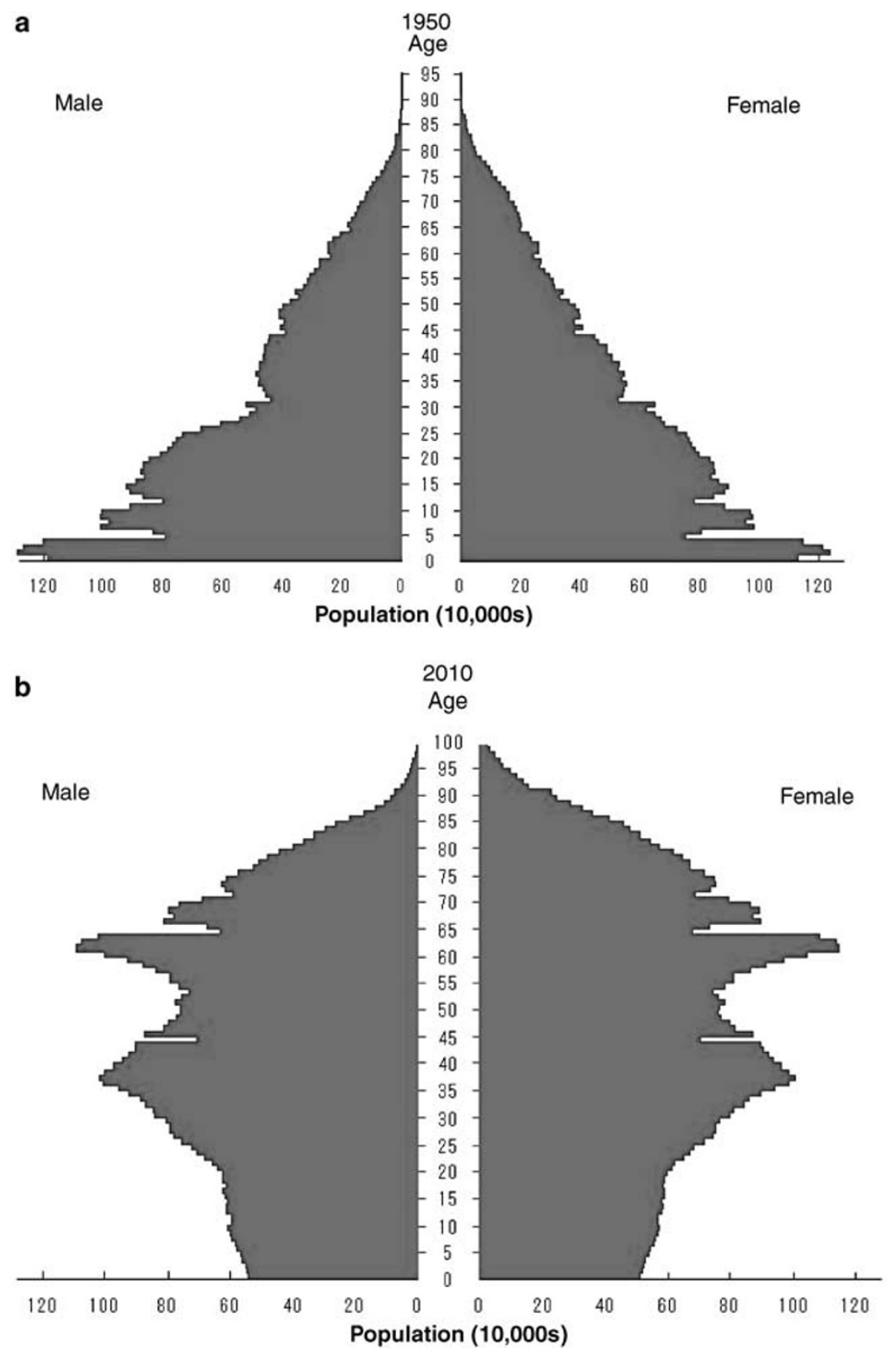

Figure 2: (a) Population pyramid comparison: Japan $1950 .{ }^{30}$ (b) Population pyramid comparison: Japan 2010 (projected) ${ }^{31}$

The dramatic demographic shift puts the PAYG public pension system in a precarious position: how to fulfil benefit promises to an expanding base of retirees while the contribution base of current workers is shrinking. To make matters worse, the benefit promises themselves had increased considerably during the highgrowth period in a deliberate effort to share the fruits of the period with those no longer in the workforce. Finally, the growing government deficit that had emerged in the aftermath of the bubble economy seemed incapable of providing a government bailout. The situation on the public pension side then put increasing pressure on corporate pensions to fulfil a greater role in the post-retirement equation for Japan. 


\section{The 'Big Bang' shock: Pension accounting standards}

The international trends in pension accounting and the overall globalisation of accounting standards increased pressure on Japan to adopt more stringent pension accounting and disclosure requirements. In globally competitive industries, the lack of pension accounting in Japan was deemed unfair, a source of hidden liabilities and a false source of global competitiveness. Adopting pension standards, however, involved an implicit treatment of pensions as 'deferred compensation' since the operating expense on the income statement and the liability on the balance sheet represented the present charge and net present value of the obligation, respectively (with various mechanisms to smooth the short-term gains and losses over time). Introducing a pension liability on the balance sheet and disclosing the full extent of pension assets and liabilities in the footnotes made transparent for the first time the status and questionable ability of corporate pensions to assume a stronger role in the three-legged stool ${ }^{12}$ of retirement savings. ${ }^{13}$

Japanese companies stumbled onto this situation after many years of experience managing stable plans and comfortably surpassing the promised rate of return. The introduction of pension accounting standards was a shock to the system because, as explained in the next section, it heightened awareness and urgency to restructure something companies could not fix so easily.

\section{The restructuring corporate challenge}

The lifetime employment contract made it difficult for companies to restructure or downsize nimbly. The procedural and legal red-tape governing layoffs, as well as the associated social stigma reinforced a residual labour market rigidity and encouraged companies to freeze hiring instead of layoff existing employees. Since the legacy of the lifetime employment contract carried a steep earnings profile, many companies wished to lower this and replace seniority-based increases with pay-for-performance metrics. The growing weight of the baby-boomer employees in the mid-to-upper echelons of the organisation bore significant weight to the payroll scale; especially in light of hiring freezes and the smaller size of younger cohorts. ${ }^{14}$ In terms of pensions, the overhaul or redesign of a pension plan was far from simple, especially as part of a broader personnel initiative to revise the lifetime employment contract.

A typical reform of the pension plan has carried larger implications to the earnings curve, the process of evaluating and rewarding employees, the role and calculation of pensions within the employees' overall compensation package and the incentives for employees to bear more responsibility for their post-retirement life. Taken as one, it helped the company formulate a newly revamped and consistent personnel policy.

Meanwhile, a perfect storm in pension terms was brewing in the macro-economy, which carried dire consequences for companies in the face of new pension accounting standards. Specifically, near-zero interest rates reduced the discount rate used to calculate the pension benefit obligation (PBO). Low investment returns reduced the actual and expected return on pension plan assets. Taken together, the pension liability ballooned and a higher present charge contained in operating expense further exacerbated the persistence of low margins at Japanese companies. ${ }^{15}$

The urgency created by new accounting standards made apparent certain inadequacies in the system: (1) 'daiko henjo', or the putback of the government portion of the company's DB plan; (2) options to convert rather than dissolve DB plans and (3) an improved safety net for beneficiaries. All of these required some form of divine - or better yet, political - intervention, which, as we describe below, proved difficult.

\section{Political deadlock}

Discussions about DC plans surfaced in 1996 under the Hashimoto Cabinet. Former Prime Minister Hashimoto and many outside observers garnered hope from the US example and the spectacular growth of DC or so-called '401(k)' plans. ${ }^{16}$ For the US, $401(\mathrm{k})$ plans provided a mechanism to stimulate savings. In contrast, debate over DC legislation in Japan occurred at a time when the nation's saving rate was under foreign criticism for being too high and its imports too low, even though the government was trying to initiate consumption-led economic 
recovery. This political beginning and blind deference to the US were considered fatal flaws by some in the bureaucracy who viewed this as a serious miscalculation of the complexities of pension reform. ${ }^{17,18}$

By the time Japanese Diet passed its DC law, it was 2001 and three cabinets later under Prime Minister Koizumi. At this point, expectations had soared and soured. Many foreign entrants from the US 401(k) business had cut their losses and pulled out of Japan. Companies and market participants had been disappointed several times with delays and issue reprioritisation. ${ }^{19}$ Even among those who felt confident that the reforms would eventually pass, they were well aware that Japanese politics could serve to change attributes in the final hour, particularly in a 'watered-down' sense. For companies, this bore particular relevance to any concrete discussion of plan reform or design. Most companies preferred to wait versus guess. For example, even a company like IBM, with its vast experience implementing DC plans around the world, lamented over how they had to be slow and deliberate in order to compensate for the uncertainty and ambiguity associated with the timing and eventual form of the legislation..$^{20,21}$

The DC Act itself was disappointing to many. In its original form, the maximum contribution limit was set at $¥ 432,000$ (approximately $\$ 3,600$ ) per year for employees of companies that do not have alternative pension systems and $¥ 216,000$ (approximately $\$ 1,800$ ) per year for employees with other types of pension plan offerings. ${ }^{22}$ This meant that the full conversion of an existing plan was not possible for many companies. The DC legislation also stipulated against early withdrawals from employees before they reached the age of 60 and did not permit employee contributions. This kept the assets small and locked in. In contrast, the US 401(k) DC system contained more features of a tax-deferred saving system based on employee contributions primarily, with employer-matching pension features secondarily. The maximum annual contribution limit by individuals at that time in the US was $\$ 10,000$. Withdrawal exemptions further helped employees liquidate or take a loan against their pension assets under special circumstances such as higher education, first-time house purchase or financial duress.
The form and timing of the DC legislation in Japan reveals how the hesitance towards adopting DC plans in Japan has not reflected paternalism as much as an unsatisfactory and overdue choice. The role of the new pension accounting standards then became one to create the urgency to tip the scales in favour of difficult restructuring programs, including the employment contract. While the form of the new legislation has constrained the growth of the DC market in Japan, it has undoubtedly influenced the overall picture of corporate pension reform in Japan. In light of recent developments in the US, we now assess how the various disappointments in the DC legislation may be viewed as system-saving features for Japan where today, DB plans remain a vibrant part of Japan's corporate pension system.

\section{Unintended consequences}

Since the low contribution caps set forth in the DC legislation prevented many Japanese companies from fully converting an existing plan to DC, these plans represent just part of the corporate pension reform story in Japan. Another option receiving more attention from corporates is the cash balance (CB) plan, a hybrid form of a DB plan made possible through the Defined Benefit Occupational Pension Act of 2002. CB plans have proven to be a good 'fit' for Japanese companies as they combine what many consider the best features of DC and DB plans, and exemplify a shared-burden or compromise typical of Japan labour relations historically. Furthermore, the accrual pattern in a CB plan tends to be much flatter than in a traditional DB plan, so the common restructuring goal of reducing the steepness of the senioritybased wage curve can be achieved through this transition. As a result, CB plans have emerged as a popular plan choice in Japan. ${ }^{23}$

Proponents of CB plans in Japan underscore the view that DC plans do not represent the optimal solution for all companies because, in removing the financial risk associated with $\mathrm{DB}$ plans, DC plans also lose the positive personnel attributes of DB plans. It is there that many companies and employees find a common middle ground in the CB plan, which seems to suggest an optimal solution to the so-called 'benefit 
conundrum'. In contrast, DC plans shift the entire investment risk to employees, which forces them to take sole responsibility for investment decisions, returns and adequate post-retirement planning. Older employees, in particular, are less familiar with making personal investments so the learning curve and risk aversion associated is large.

Grandfathering older employees in a DB plan while shutting off younger workers, however, has the effect of speeding up the cash requirements since the plan is primarily paying out benefits. The transition to a DC plan is complex requiring the expertise of pension consultants and actuaries. Within the company, a PR campaign for employees must be followed by a sufficient investor education programme. ${ }^{24}$

Some industries, though, like Retail prefer DC plans because of high levels of turnover and a younger employee base that responds well to investment and self-responsibility. ${ }^{25}$ Fortunately for these companies, subsequent lobbying by the business community has helped. In October 2004, the maximum allowable non-taxable contributions by employers increased considerably. In the following year, the restrictions on withdrawals were relaxed. As of the end of June 2006, 7,168 companies have introduced DC plans in Japan; up 51 per cent from the prior year. $^{26}$

Adoption rates of DC plans are also higher at smaller companies because of the scale and resources often lacking to set up and manage a DB plan. Many of these companies also face a looming deadline for their tax-qualified pension plans (TQPP), which are facing extinction in 2012. For these companies, DC plans offer an attractive conversion option. ${ }^{26}$

In the face of challenging demographics - no more challenging than in Japan, we view recent pension restructuring with optimism. For an economy that is emerging from a prolonged recession intact, Japanese corporate pension plans appear well positioned to face the next challenge: a wave of baby-boomers heading into retirement. Taken together with low fertility rates, Japanese corporate actors anticipate labour shortages, higher taxes and social payments and declining demand in the domestic market.

\section{Looking ahead: The 2007 problem}

The so-called '2007 problem' refers to the period when Japan's baby-boomers begin to retire en masse. This is now deemed 'a crisis' by over onethird of companies, and over 80 per cent of companies are planning some kind of countermeasure, according to a recent survey conducted by the Ministry of Health, Labour and Welfare. ${ }^{27}$ With mechanisms to induce labour market entry, influence retention and encourage retirement, DB plans (including $\mathrm{CB}$ hybrids) represent an effective HR management tool. Since DC plans separate the compensation each period with perfect portability after vesting, their retention features are relatively low. As hiring and retention increase in importance in an anticipated talent shortage, DB plans offer a tool to management that DC plans lack. In particular, the question of how to efficiently rehire and utilise seniors is arguably better conceptualised within a DB pension framework, taking into consideration the other legs of the retirement stool. In this light, corporate pension plans may be optimised to assist with a company's people strategy, rather than simply reducing a liability on the balance sheet.

Traditionally, the oversight of pensions had relatively low influence within the corporate structure. New pension accounting increased the visibility of pensions on the financial statements as well as within the minds of top management. In the midst of Japan's lost decade, pension accounting arrived at a period of unprecedented operating weakness, ongoing economic uncertainty and low corporate confidence. Existing institutions such as the legal and tax systems and the lifetime employment contract initially hindered companies from reforming their pension systems. The new standards, however, exposed these deficiencies and created the urgency to push through important pension reform initiatives.

\section{Looking ahead to reform in the US}

The renewed focus and negativity on DB plans in the US - both at the private and public sector levels - has led companies to re-evaluate their plans. Between 2000 and 2004, many constituents of corporate America produced poor returns from the equity markets, which, coupled with low 
interest rates, triggered significant changes in many companies' funding status' (130 per cent funding status to less than 80 per cent over a five-year period). The dramatic shift brought about the need for change in pension plan regulations and pension management, and disclosing the true unfunded liability on the balance sheet rather than buried in the footnotes. This change would make transparent the discrepancy between the plan assets and the promises made to current and future retirees.

As a response to the need for more transparency and economic reflection in the accounting, the FASB initiated a two-phase project with the first phase of the project, as an official amendment to the US' Generally Accepted Accounting Principles (GAAP), to require companies to eliminate the smoothing on their balance sheet and disclose the real obligations. The second phase will commence in 2007 and attempt to converge the existing US standards with International Financial Reporting Standards (IFRS) adopted by the International Accounting Standards Board (IASB). This phase will tackle the question of what should be recognised through earnings - possibly on a mark-to-market basis (ie no smoothing). In response, many companies have already frozen out their existing pension plans (eg IBM) and have switched active employees to a combination of deferred benefits such as DC plans or a heavier reliance on long-term equity incentive plans.

The US government introduced legislation a year ago with subsequent modifications this past summer which in essence will reshape existing funding rules and make it hard for most industries ${ }^{28}$ to let their plans evolve to a precarious state. New funding requirements including less smoothing (previously made available via tax rules), accelerated amortisation of past costs and increased premiums per beneficiary is a direct response to the need to shore up the PBGC and create more fluid funding to this agency. Based on previous funding rules, the PBGC inadvertently encouraged companies to play aggressive with their funding as the premiums set by congress were set at low fixed rates irrespective of the actual demographics of the beneficiaries or the macro-conditions of the sponsors' industry. As a result, within a two-year time-frame, the PBGC went from a surplus to a significant liability and now faces the potential of taking on more plans of bankrupt companies.

We expect the new legislation to have some short-term impact on companies, but it is likely that reforms in financial reporting and capital market pressures will force companies to make more structural changes. For example, the rating agencies, in the wake of other scandals, have revised their approach to how they treat unfunded post-retirement liabilities. Declines in ratings from improved credit analysis will only increase the cost of borrowing and bring more attention to the inherent risks facing companies. There is cause to believe that the rating agencies, may go even further, depending on the demographics (eg age) of the plan, and look towards counting a plan's equity exposure as a form of corporate leverage. In this scenario, the agencies would assess whether additional risk arises from the mismatches of the duration of the plan assets returns relative to the expected time-frame of beneficiary payouts.

\section{Conclusions}

The trend in global demographics of an ageing global workforce and the above external factors point to new challenges faced by corporates in the US and Japan. These challenges are not insurmountable but they require new strategies to cope with a different set of risks outside of the playing field of their industries. Going forward we expect reform to tighten not only by the external factors such as accounting standards and pension reform legislation, but also within the ranks of individual corporate governance reforms. For example, we expect management teams to incorporate pensions into their overall corporate finance decisions with more moves towards tax efficient funding and trading strategies. In many cases, companies will revert from managing their plans on an absolute or benchmarking basis and reallocate more to fixed income and alternatives (as opposed to equities) as part of a move towards a more sophisticated approach of matching the plan assets against the liabilities.

We end with a word of caution that not all individual corporate reform is equal. Some 
responses such as freezing current plans, increasing DC contributions or matching and reducing cash flow exposure from asset allocation risks fall short of addressing the risks associated with the remaining beneficiaries and their expected benefits. Other responses go a step further to address long-term HR strategies and demographic concerns. These typically entail a plan re-design and a broader alignment with employee compensation and performance evaluation. We applaud these efforts and expect other companies to follow suit as the demographic crisis hits closer to home. The question for these companies will be: is it too little too late?

\section{Acknowledgments}

All findings, interpretations and conclusions of this paper represent the views of the authors and not those of Lehman Brothers, Morgan Stanley, the Wharton School or the Pension Research Council. The authors benefited from discussions with David McLellan and are grateful for his pensioner's perspective. They are also indebted to support and feedback from Ken Shibusawa and Jennifer Amyx.

\section{References and Notes}

1 This expresses the ratio of working age population (age 15-64) to pensioners. In 1950 , there were 50 workers per retiree. In 2050 , the ratio is expected to drop to 2.5 to 1 in the US, and just 1 to 1 in Japan.

2 FASB: Financial Accounting Standards Board. www.fasb.org.

3 The 'lost decade' refers to the period of economic stagnation following the bursting of the bubble.

4 Underlying this was the structural shift of ownership structure and, specifically, the shift from a dominant bank governance model to an increasingly foreign-based shareholder ownership structure. See McLellan, S 2006 'Evolving Corporate Governance', Presentation to the Japan Society of Northern California, San Francisco, 28th June www.usajapan.org.

5 Berner, R. (2006) 'Financial implications of pension reform: Update', Morgan Stanley Research, New York, 4th August.

6 Berner, R. and Harris, T. (2006) 'Financial implications of pension reform', Morgan Stanley Research, New York, 18th January.

7 After the tax code that granted the favourable tax treatment of DC plans in the US and subsequently increased their popularity.

8 Wooten, J. A. (2006) 'Recent pension legislation in the United States, Presentation to the Japanese Pension Research Council, Tokyo, 25th August.

9 Mitchell, O. (2006) 'Older workers: Untapped assets for creating value', Knowledge@Wharton', Philadelphia, 9th February.

10 Under the Japanese commercial code, companies do not have the same incentives and can legally operate some types of pension plans highly underfunded without penalty (or safety net).

11 Nenkin ga kaisha wo kowasu (transl. Pensions will destroy companies)Nikkei Business, Tokyo, 16th June, 2003.

12 The three-legged stool represents (i) corporate or public pensions, which defer compensation; (ii) personal saving, in which individuals defer consumption and (iii) the government safety net, which makes promises based on future economic growth. Morgan Stanley's Richard Berner ascribes two additional 'legs': working longer and access to health insurance benefits.

13 Berner, R., and Peskin, M. (2006) 'Derisking' corporate Pension plans: Options for CFOs', Morgan Stanley Global Pensions Quarterly, Spring, New York (Spring).

14 In a traditional lifetime employment wage model, younger employees were paid less than their contribution in the early years of employment to induce retention. As older employees, they would recoup the 'lost wages', but in effect, the company was paying back a loan to employees at a cost higher than their current productivity.

15 Near-zero rates indicate that the present value and the future value of the labour obligations are almost the same making the obligation much more 'near-term'. In comparison, US companies calculate pension obligations on rates roughly 650 basis point higher. This difference indicates that the risks of cash flow requirements are more short-term oriented in Japan, all else equal.

16 DC plans became popular in the US starting in the late 1970s after Congress added $\$ 401(\mathrm{k})$ to the tax code (1978) and the US Treasury issued regulations outlining their requirements (1981).

17 Yano, K. (2003) 'Personal communication with author', Tokyo/ Philadelphia.

18 Wakasugi, T. (2003) 'Personal communication with author', San Francisco.

19 McLellan, S. I. (2004) 'Corporate pension reform in Japan: Big Bang or Big Bust? Pension Research Council Working Paper No. 2004-05, Philadelphia.

20 Roin, K (2003) 'Personal communication with author (telephone)

21 Tsubota, K (2003) 'Personal communication with author', Tokyo.

22 Based on October 2001 levels (approx $\$ 1=¥ 120$ ).

23 Cash Balance plans have been controversial in the US due to allegations of age discrimination. Recent court decisions have, however, reversed some of the controversy, providing hope that hybrid plans may once again gain favour among US companies. See Cooper v IBM Personal Pension Plan, United States Court of Appeals for the Seventh Circuit, Case No. 05-3588 (Decision: 7th August, 2006).

24 Plan conversion requires Union approval or 2/3 employee consent.

25 Shimizu, M. and McLellan, S. I. (2006) 'Department Stores: Pensions Provide an Unexpected Glimmer', Morgan Stanley Research, Tokyo, 22nd August.

26 Participants in Japan 401(k) plans set to top $2 \mathrm{~mm}$. Nikkei Shimbun, Tokyo, 17th August, 2006.

27 MHLW: Ministry of Health, Labour, and Welfare. www.mohlw. go.jp.

28 Some industries such as Airlines still get lenient breaks (ie amortisation periods and funding durations extended) which is indicative of the 'system' to continue to subsidise noncompetitive industries.

29 Source: Pension Fund Association. Annual Report of Employees' Pension Funds. www.nikko-fi.co.jp/uploads/photos1/269.pdf.

30 Source: National Institute of Population and Social Security Research. www.ipss.go.jp

31 ibid. 